\title{
Márcia Denser
}

Como você pensa a relação entre o tempo literário e o tempo histórico?

A mediação entre tempo literário e histórico é feita numa "faixa sintônica" - ou na sintonia - de vida e literatura, é aí que se dá a fusão de ambos.

Quer dizer, isto acontece se os fatos narrados ocorrem no presente, foi diferente quando escrevi meu romance Caim, cuja ação transcorre entre 1850 e 1979 e sempre se reporta ao passado (ainda que esta se apresente "presentificada", no diálogo, não só como raconto, no relato).

A subjetividade da escritora é particularmente sensível ao tempo histórico enquanto "espírito de época", nele ela vive, sofre, ama, odeia etc. e a essência dessa vivência engendra o tempo literário. Ou melhor, quando essa vivência "se essencializa", vira literatura.

\section{Quais procedimentos sua obra adota diante de} um mundo em que predominam a ação econômica e a espetacularização da arte?

Vou explicar o óbvio: um escritor ruim ao fazer a crítica de "hegemonia econômica" e "espetacularização da arte" corre o risco de datar o texto, contudo os contos da Diana caçadora já faziam essa crítica nos anos 1980 e permanecem atuais, porque são literatura, razão pela qual os maiores fãs e leitores da personagem Diana Marini são os jovens autores $e$ autoras das novas gerações. Minha criação é crítica e vice-versa. A obra de arte cresce com o tempo, a obra menor desaparece. As minhas referências textuais ao histórico, passageiro, contingente, não se traduzem como citação, comentário, elemento descartável ou "a mais" dentro da composição literária - em fiç̧ão não se joga nem meia palavra fora - mas como estrutura estética.
Qual reflexão sua obra produz sobre a tradição literária brasileira?

Nos anos 1980, representou um avanço para uma literatura dita feminina e feminista no Brasil, uma vez que representa a mulher como sujeito da ação e não como objeto do homem e do texto do homem. Mas desde então, esse, digamos, rótulo, descolou - e novamente me reporto às considerações dos escritores da nova e novíssima geração - e sinto que sou considerada uma escritora que privilegia a linguagem. E como literariamente forma \& conteúdo são indissociáveis, pode-se detonar qualquer revolução a partir daí, certo?

\section{Como você pensa a forma literária?}

Como indissociável do conteúdo, meu bem.

Márcia Denser (1954) é autora de Tango fantasma (Ateliê, 1977), Oanimal dos motéis (Civilizaçăo Brasileira/Massao Ohno Editores, 1981), Muito prazer (Record, 1982), O prazer é todo meu (Record, 1984), Exercícios para o pecado (Philobiblion, 1984), Diana caçadora (Ateliê, 1986), A ponte das estrelas (Best Seller, 1994) e Toda prosa ll: obra escolhida (Record, 2008), entre outros. 